\title{
DETERMINANTS OF ENTREPRENEURIAL INTENTION AMONG ENGINEERING STUDENTS: APPLICATION OF THEORY OF PLANNED BEHAVIOUR
}

\author{
MADHUKARA NAYAK ${ }^{1}$, NARASIMHA MARAKALA ${ }^{2}$, VASANTH KAMATH ${ }^{3} \&$ U. SAIKRISHNA $^{4}$ \\ ${ }^{I}$ Shri Madhwa Vadiraja Institute of Technolology and Management, Bantakal, Udupi, India \\ ${ }^{2}$ NMAM Institute of Technology and Management, Nitte, Udupi, India \\ ${ }^{3}$ T. A. Pai Management Institute (TAPMI), Manipal, Udupi, India \\ ${ }^{4}$ Advanced System Laboratory (DRDO), Hyderabad, Telangana, India
}

\begin{abstract}
Entrepreneurs are "the engines of economic growth." They also contributed immensely to the constructive commitment of a nation to economic prosperity and social progress. Contributions include the invention and creation of employment opportunities. Since entrepreneurship is associated with self-employed individuals, it is perceived to be an effective approach to address the challenge of employability, especially among young people. Therefore, recognizing the variables that determine entrepreneurial motivation is important since entrepreneurial behavior is the result of purpose. This research aims to identify the factors of entrepreneurial inspiration and purpose between final year engineering students. As most research suggests that entrepreneurial motive may be calculated through the use of Planned Behavior Theory (TPB), this principle is utilized as a theoretical foundation in this research. The main parameters of this research are personal behaviors, perceived social guidance, and perceived behavioral management. This theoretical paradigm has been tested with 372 final year engineering students at engineering colleges in the coastal Karnataka part of India. Findings have shown that personal perception, presumed behavioral influence, and perceived social assistance are indicators of entrepreneurial motive. This research will assist policy departments, organizations, researchers, business students, advisors, and other stakeholders in identifying suitable ways to promote entrepreneurship in higher education institutions and, ultimately, in the community.

KEYWORDS: Entrepreneurial Intention; Theory of Planned Behavior; Perceived Relational Guidance; Personal Perception \& Perceived Behavioral Management
\end{abstract}

Received: Jun 09, 2020; Accepted: Jun 29, 2020; Published: Aug 13, 2020; Paper Id.: IJMPERDJUN2020761

\section{INTRODUCTION}

Currently, entrepreneur innovation has been granted significant attention because of its relevance to economic development, employment opportunities, invention, and profitability growth (Urbano and Aparicio, 2015). Developing nations such as India are also encouraging graduates to be interested in entrepreneur innovation and to see this innovation as a milestone in their career option. This is well recognized that in the future, students are an essential component of emerging entrepreneurship.Some of the federal state'sattempts to promote entrepreneurship among higher institutions of learning and college students are to render entrepreneurship mandatory for all graduates, irrespective of their research profession. Entrepreneurship is critical for economic growth and development, employment, and the alternative to the unsustainable rate of university students and societal challenges. It is also necessary to recognize the parameters that affect university graduates' ambitions to initiate a new or innovation project. 
According to Fayolle and Linan (2013), who also was referenced by Karimi et al. (2014), there is still minimal literature on the above phenomenon, while entrepreneurship has been seen as central to economic advancement. In this regard, there is a need for research to be undertaken to recognize the factors of students interested in entrepreneurship and to promote the growth of insight and increase awareness in this field. This research will enable policy departments, organizations, researchers, market students, consultants' experts, and stakeholders to recognize appropriate ways to facilitates entrepreneur innovation in higher education institutions and, ultimately, in the community.

\section{LITERATURE REVIEW AND HYPOTHESIS}

\section{Theory of Planned Behavior (TPB)}

The (TPB) was established by Ajzen (1991) as an expansion of the Theory of rational action (T.R.A.) which was invented by Fish be in and Ajzen (1975). In addition, Engle et al. (2010) suggested that the TPB paradigm is used as an essential cognitive cycle paradigm for the assessment of entrepreneurial motive. This paradigm illustrates the dynamics of the interaction among human actions and their related predictors. Perhaps notably, it recognizes individual acts as a source of purpose and motive. In addition, Ajzen (1991) illustrated that the drive is specifically influenced by the following three histories origins: I mindset and sense of entitlement; (ii) social norm; and (iii) assumed behavioral management. Consequently, the three variables listed above specifically impacts a person's decision to conduct a behavioral action. The researcher also states that the TPBmay be seen in most other areas of concern, especially in the interpretation of such habits as buying behavior, recreational activity, drinking activity, etc.

Krueger et al. (2000) find out that innovation in an entrepreneur is a product of deliberate and expected behavior. Therefore, the usage of the TPB to evaluate entrepreneurial motive is deemed feasible. In reality, according to van Gelderen et al. (2008), TPB has been described as an essential and prominent paradigm for the research and interpretation of entrepreneurial motives. This illustration has also been approved by Shook and Bratianu, (2010) and Moriano et al. (2011), who came up with similar illustrations.

\section{Personal Attitude and Entrepreneurial Motive}

According to Petty et al. (1997), the principle of perceptions is essential to recognizing how practice contributes to susceptibility in perceptions. Krueger et al. (2000) defined that mentality as a long-lasting pattern of positive or negative assessments of an entity. In addition, according to Hoyer and Maclnis (2004), this reflects the way a human considers and contrasts an item with the choices available on the grounds of personal reasoning (cognition), opinion (values), and feeling (affection)to a specific entity. Maes et al. (2014) proposed that individual expectations and perceived behavioral actions function implicitly with societal standards to determine an individual's desire to participates in entrepreneur innovation.

Consequently, Mumtaz et al. (2012) observed that the mindset of university graduates had a significant effect on their choice to pursue an entrepreneur as a profession. In essence, a constructive perspective on behalf of students is more inclined to affirm the person's desire to engage in entrepreneur innovations and activities. It contributes, however, to the subsequent hypothesis.

Hypothesis 1: Individual perception has a favorable effect on entrepreneurial purpose 


\section{Perceived Relational Assistance and Entrepreneurial Motivation}

However, Türker and Selçuk (2009) illustrated that interpersonal encouragement relates to the acceptance and assistance of family members, colleagues, and others to participate in entrepreneurial ventures. Besides, family and associates are all who have a tremendous impact on personal career decisions as they are perceived to be fund managers and mentors. Nanda and Sorensen (2009) argued thatit is discovered in the literary works that the involvement of friends and mentors is popular in controlling the choice of becoming an entrepreneur. The influence of mentors on the propensity for entrepreneurship is extensively explored in the literary works (for instance,Kirkwood 2007; Karimi et al. 2013). This is attributed to the fact that mentors also have the requisite details, direction, successful illustration, and encouragement (Postigo et al. 2006). By providing an intense experience and assistance, learners become more willing and comfortable to be an entrepreneur. In addition, this is supposed to empower and encourage the person to become a good entrepreneur.

Based on the findings of Nanda and Sorenson (2009), which focuses on the research of young Australians who found that associates had a significant impact on their choice to begin a venture.Sergeant and Crawford (2001) researched the same study and obtained similar findings. In addition, froYurtkoru et al. (2014) research, it was also observed that help from families, colleagues, and a strong network of 425 Turkish undergraduates had a substantial impact on their choice to be an entrepreneur. Equally, in a sample of university hospitality graduates in the United Kingdom, Altinay et al. (2012) showed that the entrepreneurial history of the family was strongly linked to the entrepreneurial purpose an ambition.

Hypothesis 2: Perceived mutual or relational encouragement has a beneficial effect on entrepreneurial motivation.

\section{Perceived Behavioral Control and Entrepreneurial Intention}

Perceived behavior management indicates the apparent capacity to conduct desired actions (Ajzen, 1991). According to Ajzen and Driver (1992), it corresponds to an individual's understanding of the extent of simplicity and complexities in executing these activities and is supposed to represent past exposure as well as everyday challenges. This aspect is affected by expectations of exposure to the expertise, services, and incentives required conducting behavior. If an individual believes that he or she is in charge of the behavioral influences, he or she can encourage the purpose of performing the specific behavior. On the other hand, if that individual may not have influenced the situation, he or she may have more or less purpose in conducting particular actions.

Consequently, according to Ajzen and Driver (1992), who was also referenced by Burton (1991), perceived behavior affects and impacts the ability to manage behavior. Several studies have found that there is a connection between perceived behavioral influence and behavioral purpose. Multiple types of research show a significant association between perceived behavioral impact and entrepreneurial purpose (Covered, 1996; Autio et al., 2001;Zhang, 2015; Solitaries et al., 2006; Gelderen et al., 2008; Tegtmeier, 2012; Yang, 2013;Krueger et al., 2000).

The third hypothesis is illustrated as H3: perceived behavioral influence is significantly linked to entrepreneurial motive and purpose. On the basis of these results, it can be suggested or assumed that:

Hypothesis 3: Perceived behavioral influence has a beneficial effect on entrepreneurial motivation and purpose.

\section{Entrepreneurial Intention}

Ajzen (1991) demonstrates motivation as"an indicator of how much individuals are likely to attempt, how much commitment they are preparing to make to satisfy their behavior." Typically, the greater the motive, the more probable an 
individual is to conduct a specific action. $\mathrm{Wu}$ (2010) suggested that it is realistic to analyze motivation or intention, as the study's real behavior is challenging to quantify. Entrepreneurship's aim andpurpose are strongly linkedto the conduct of entrepreneurship.

Ajzen (1991) also suggested that intention is a strong predictor of behavioral performance. In additionto that, Krueger et al. (2000) have suggested that entrepreneurial activity is deliberate and expected. This is because the entrepreneurial activity is intentional; several scholars have concluded that entrepreneurial motive and purposecan be forecast as demonstrated by (Krueger and Carsrud, 1993).

\section{THEORETICAL FRAMEWORK}

Utilizing the paradigm of planned behavior to test entrepreneurial motivation was observed in different experiments, for instance, do Paço et al. (2011), Fini et al. (2009), Kautonen et al. (2009, 2010), Mariano et al. (2011) and Sommer and Haug (2011), only to mention several. Regarding previous literary works, this research also adjusts TPB to evaluate parameters influencing the ambition of university students to become entrepreneurs. Figure 1 demonstrates the study paradigm

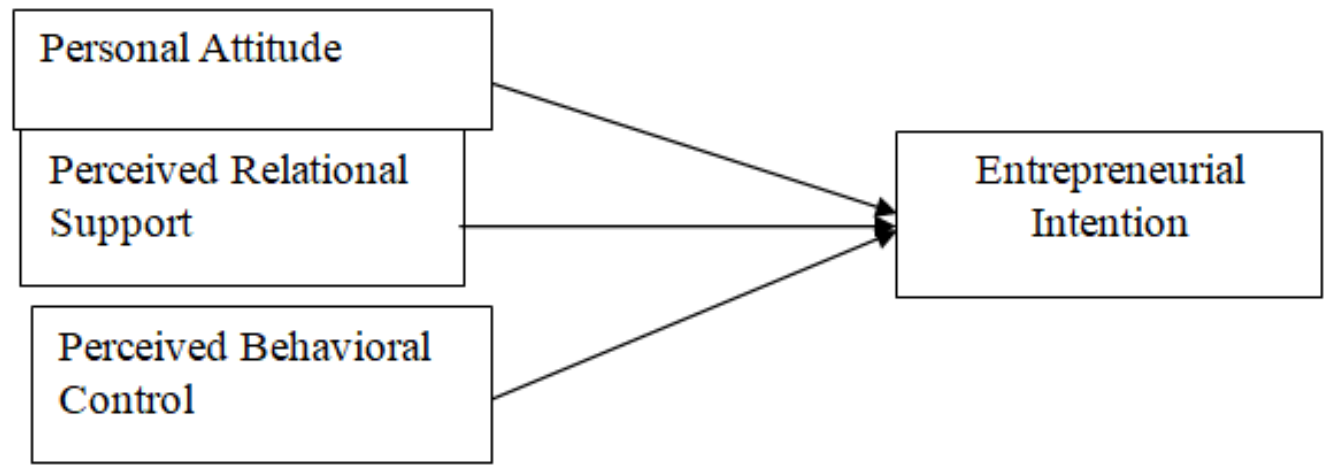

Figure 1: Theoretical Framework.

\section{METHODOLOGY}

\section{Population and Sampling}

The population of this research is comprised of final year undergraduates from engineering colleges in the coastal Karnataka area in India. Basically, the collection of the sample would be performed using a simple random sampling procedure. It is assumed that when utilizing this selection process, participants from different fields of research will be portrayed. Final year engineering students are considered suitable samples since they are young and can be identified as "younger peer group." In fact, they can go on to their professional life immediately after graduating; becoming an entrepreneur may be a career progression for them. The value of the usage of students at the university as participants of research can also be seen in Ismail et al. (2009), Shook and Bratianu (2010), van Gelderan et al. (2008), and Yusof et al. (2007).

\section{Research Instrument, Data Collection, and Data Analysis}

The questionnaire is the technique to be included in this research. Furthermore, self-administering questionnaires will be utilized since it will discourage participants from being manipulated by investigators. All the elements in the questionnaires are to be established through comparison to previous research. Basically, five-point Likert-scale questions should be 
formulated.

Data was gathered in a class facility environment in which the participants were granted 10 to 15 minutes to address the queries of the administered questionnaires. It is intended to ensure that there is adequate opportunity for the participants to address the queries and to achieve a good response percentage.

Data was then evaluated using the Partial Least Squares (P.L.S.) and Structural Equation Modeling (S.E.M.) method. The study and evaluation of the P.L.S. framework is a two-stage operation. First is the evaluation of the precision and relevance of the estimation model, and the latter is the evaluation of the theoretical framework to evaluate the research topic's assumptions. Such evaluations are described in the following segments.

\section{DATA ANALYSIS AND THE FINDINGS}

\section{Assessment of the Measurement Model}

The first phase in the P.L.S. research was to evaluate the estimation paradigm (or the outer framework) to decide how concise the metrics (variables in the frameworks) are mounted on the theoretically described paradigms. It was assured that the research tool was accurate and appropriate for the assessment of the specification that was intended to be computed. Consequently, the intrinsic accuracy, indicator precision, convergent reliability, and discriminant consistency of the assessment model are evaluated. For this analysis, the intrinsic quality or composite durability of each design varies from 0.844 to 0.906 and is above the required target value of 0.70 .

Consequently, the findings suggest that the objects utilized to depict the structure have sufficient internal consistency reliability. The predictor reliability ranging from 0.419 to 0.801 was better than the expected value of 0.40 . The mean derived variance is utilized to check the convergent accuracy. The findings of the study reveal that all AVE concepts vary from 0.539 to 0.661 , which indicates sufficient consistency invalidity. Prejudiced credibility is a contrast to symmetric rationality. It shows the extent to which one design differs from the other. It can be measured utilizing two estimations; I cross-loading and ii) FornellLarcker's (1981) criteria. In this analysis, the differential validity of the estimation paradigm was resolved, and the finding indicated that the Fornell and Larker standards would be achieved.

\section{Evaluation of Structural Model}

Table 1 below demonstrates the effects of the findings of this research. The R squared score was 0.622 , indicating $62.2 \%$ of the entrepreneurial motive variation can be clarified by individual behavior, perceived behavioral influence, perceived assistance, perceived social assistance, and perceived systemic support. Personal learning attitudes (Hypothesis 1), perceived behavioral effect (Hypothesis 3) and perceived social assistance (Hypothesis 2) were strongly linked to entrepreneurial motivation and purpose. Table 1 reveals that personal behavior $(\beta=0.462, \mathrm{~T}=10.039, \mathrm{P}$ value $=0.000)$ is the most important indicator of entrepreneurial motivation among graduates, accompanied by regarded behavioral influence ( $\beta=0.237, T=4.742, P=0.000$ ) and perceived social assistance ( $\beta$ was estimated to be $0.183, T=3.854, P$ value was 0.000 )

Table 1: Results of Hypothesis

\begin{tabular}{|l|l|c|c|c|l|}
\hline Hypothesis & Relationship & $\begin{array}{c}\text { Standardized Coefficients } \\
(\text { Beta) }\end{array}$ & $\boldsymbol{T}$ Value & Path Coefficient & Supported \\
\hline Hypothesis 1 & A.T.B. $\rightarrow$ EI & 0.462 & 10.039 & $0.000^{* *}$ & Yes \\
\hline Hypothesis 2 & S.N. $\rightarrow$ EI & 0.183 & 3.854 & $0.000^{* *}$ & Yes \\
\hline Hypothesis 3 & P.B.C. $\rightarrow$ EI & 0.237 & 4.742 & $0.000^{* *}$ & Yes \\
\hline $\mathbf{R}^{2}=\mathbf{0 . 6 2 2}$ \\
\hline$* \mathrm{P}<0.01, * * \mathrm{P}<0.05$
\end{tabular}




\section{DISCUSSIONS AND CONCLUSIONS}

The main objective of this research was to examine the determinants of entrepreneur innovation purpose among engineering undergraduates. In regard to the paradigm of Planned Behavior Theory, individual motives or activities are affected by their perceptions and beliefs. This philosophy is extensively utilized to forecast and demonstrate a variety of human behaviors and reasons. Entrepreneurship is an origin of economic development, creativity, and education; it is necessary to know the aspects that affect the ambition of graduates to become entrepreneurs. This research suggested that, out of the three assumptions proposed, all three had a significant effect on entrepreneurial motive.

First, a specific individual attitude has been shown to have a substantialimpact on the unique undergraduate'sstudent ambition to become an entrepreneur. It is therefore proposed that the larger the perception of the graduates towards entrepreneurship, the higher the entrepreneurial motives. The individual mindset in this research relates to the graduates' understanding of the benefits, motivation, and popularity of entrepreneurship. The results of this research are identical to those of Mumtaz et al. (2012) in Malaysia. Second, perceived behavioral influence has been shown to have a substantial effect on entrepreneurial motivation among engineering undergraduates. Therefore, if graduates believe that it is safer to be an entrepreneur, they would be inspired to become an entrepreneur. This observation is identical to one from Souitaris et al. (2007).

Thirdly, perceived social assistance has a huge effect on the entrepreneurial purpose. In other terms, the stronger the encouragement of parents, relatives, colleagues, and those around them, the more creative their ambition becomes. According to Yurtkoru et al. (2014), who was referenced by Zapkau et al. (2015), it is noted in the research that the involvement of cohorts and mentors is influential in shaping the choice to be an entrepreneur. These findings were also anchored by (Altinay et al., 2012; Nanda and Sorensen, 2006)

The main benefit of this study is the observational analysis of variables influencing the desire of graduate's students to be an entrepreneur. It is attributed to the assumption that, in the coming days, university students are a significant part of start-up entrepreneur innovation. The effect of this research on decision-makers and teachers is different from providing entrepreneurship course work. Universities can find certain reasons to inspire students to become entrepreneurs. For instance, in this analysis, personal activity is the most substantial impact of the university undergraduates' ambition and motivation to be an entrepreneur.

\section{REFERENCES}

1. Ajzen, I. (1991). The Theory of planned behavior. Organizational Behaviour and Human Decision Process, 50(2), 179-121.

2. Ajzen, I. and Driver, B.L., 1992. Application of the Theory of planned behaviour to leisure choice. Journal of leisure research, 24(3), pp.207-224.

3. Altinay, L., Madanoglu, M., Daniele, \& R. Lashley, C. 2012. The influence of family tradition and psychological traits on entrepreneurial intention, International Journal of Hospitality Management, 31, (2): 489-499.

4. Autio, K., Klofsten, P., \& Hay. (2001). Entrepreneurial intent among students in Scandinavia and the U.S.A. Enterprise and Innovation Management Studies, 2(2), 145-160.

5. Bird, B. (1988). Implementing entrepreneurial ideas: the case for intention”. Academy of Management Review, 13(3), 442453. 
6. Bodewes, W., Van Gelderen, M., Brand, M. J., Van Praag, M., Poutsma, E., \& Van Gils, A. (2010). Explaining entrepreneurial intentions using the Theory of planned behaviour. Career Development International, 13(No. 6), 538-559.

7. Choo, S., \& Wong, M. (2006). Entrepreneurial intention: triggers and barriers to new venture creations in Singapore. Singapore Management Review, 28 i, 47-64.

8. Davidsson, P \& Honig, B. (2003). The role of social and human capital among nascent entrepreneurs.Journal of Business Venturing, Vol. 20, pp 1-21.

9. Do Paço, A.M.F., Ferreira, J.M., Raposo, M., Rodrigues, R.G. and Dinis, A. (2011), Behaviors and Entrepreneurial Intention: Empirical Findings of Secondary Students, Journal of International Entrepreneurship, 9:20-38.

10. Engle, R.L., Dimitriadi, N., Gavidia, J.V., Schlaegel, C., Delanoe, S., Alvarado, I., He, X., Buame, S. and Wolff, B. (2010), Entrepreneurial Intent: A Twelve-Country Evaluation of Ajzen's Model of Planned Behavior, International Journal of Entrepreneurial Behaviour \& Research, 16(1): 35-57.

11. Fini, R., Grimaldi, R., Marzocchi, G.L. and Sobrero, M. (2009), The Foundation of Entrepreneurial Intention, conference proceedings in Summer Conference 2009, June 17-19, 2009, Frederiksberg, Denmark.

12. Fishbein, M. and Ajzen, I. (1975), Belief, Attitude, Intention and Behavior: An Introduction to Theory and Research, MA: Addison-Wesley.

13. Henley, A. (2007). Entrepreneurial aspiration and transition into self-employment: evidence from British longitudinal data. Entrepreneurship and Regional Development, 19(3), 253-280.

14. Hessels, J., Van Gelderen, M. and Thurik, R., 2008. Entrepreneurial aspirations, motivations, and their drivers. Small Business Economics, 31(3), pp.323-339.

15. Kautonen, T., Luoto, S. and Tornikoski, E.T. (2010), Influence of Work History on Entrepreneurial Intentions in 'Prime Age' and 'Third Age': A Preliminary Study, International Small Business Journal, 28(6):583-601.

16. Kautonen, T., Tornikoski, E.T. and Kibler, E. (2009), Entrepreneurial Intentions in the Third Age: The Impact of Perceived Age Norms, Small Business Economics, published online 18 October 2009, DOI: 10.1007/s11187-009-9238-y.

17. Karim, Shaik, and E. Lokanadha Reddy."An Empirical Study on the Attitudes of Students Towards Entrepreneurship. "International Journal of Business Management \& Research (IJBMR) 4.2, Apr 2014, 1-14

18. Kolvereid, L. (1997). Prediction of employment status choice intentions.Entrepreneurship Theory and Practice. $21,47-57$.

19. Krueger, N.F. and Carsrud, A.L., 1993. Entrepreneurial intentions: Applying the Theory of planned behaviour. Entrepreneurship \& Regional Development, 5(4), pp.315-330.

20. Krueger, N.F. Jr., Reilly, M.D. and Carsrud, A.L. (2000), Competing Models of Entrepreneurial Intentions, Journal of Business Venturing, 15: 411-432.

21. Lee, L., Wong, P. K., Foo, M., \& Leung, A. (2011). Entrepreneurial intentions: the influence of organizational and individual factors. Journal of Business Venturing, 26, 124-136.

22. Mathieson, K., 1991. Predicting user intentions: comparing the technology acceptance model with the Theory of planned behaviour. Information systems research, 2(3), pp.173-191.

23. Moriano, J.A., Gorgievski, M., Laguna, M., Stephan, U. and Zarafshani, K. (2011), A Cross-cultural Approach to Understanding Entrepreneurial Intention, Journal of Career Development, published online 6 January 2011, DOI: $10.1177 / 089484845310384481$. 
24. Mumtaz, B.A.K., Munirah, S., \&Halimahton, K. 2012.The Relationship between educational support and entrepreneurial intentions in Malaysian Higher Learning Institution, Procedia - Social and Behavioral Sciences, 69, 24: 2164-2173.

25. Nanda, R. \& Sorensen, J., 2009. Workplace Peers and Entrepreneurship (March 10, 2009). Harvard Business School Entrepreneurial Management, Working Paper No. 08-051.

26. Nakayama, Takeshi. "Entrepreneurial intention in Japan: An empirical study on Japanese university students. "International Journal of Business and General Management 5.3 (2016): 81-96.

27. Shapero, A. (1982). Social dimensions of entrepreneurship. In C.A. Kent et al. (Eds.) The Encyclopaedia of Entrepreneurship, pp 72-89.

28. Shook, C.L. and Bratianu, C. (2010), Entrepreneurial Intent in a Transitional Economy: An Application of the Theory of Planned Behavior to Romanian Students, International Entrepreneurship Management Journal, 6: 231-347.

29. Siu, W.-s., \& Lo, E. S.-c. (2013). Cultural contingency in the cognitive model of entrepreneurial intention. Entrepreneurship: Theory \& Practice, 37(2), 147-173. DOI:10.1111/j.1540-6520.2011.00462.x.

30. Sommer, L. and Haug, M. (2011), Intention as a Cognitive Antecedent to International Entrepreneurship: Understanding the Moderating Roles of Knowledge and Experience. International Entrepreneurship Management Journal, 7:111-142.

31. Souitaris, V., Zerbinati, S., \& Al-Laham, A. 2007. Do Entrepreneurship Programmes Raise

32. Entrepreneurial Intention of Science and Engineering Students? The Effect of Learning, Inspiration and Resources. Journal of Business Venturing, 22, 566-591.

33. Tegtmeier. (2012). Empirical implications for promoting students' entrepreneurial intentions. Journal of Enterprising Culture, 20(No. 2), 151-169.

34. Urbano, D., \& Aparicio, S. 2015. Entrepreneurship capital types and economic growth: International evidence, Technological Forecasting and Social Change.

35. Vanan, C. KURINCHI, and R. Subramani. "Digital divide: rural and urban college students 'attitude towards technology acceptance." International Journal of Communication and Media Studies (IJCMS) 5.4 (2015): 1-8.

36. Wu, J. (2010), The Impact of Corporate Supplier Diversity Programs on Corporate Purchasers' Intention to Purchase From Women-Owned Enterprises: An Empirical Test, Business \& Society, 49(2): 359-380.

37. $W u, S ., \& W u, L .(2008)$. The impact of higher education on entrepreneurial intentions of university students in China. Journal of Small Business and Enterprise Development, 15(4), 752-774.

38. Yang. (2013). The Theory of planned behaviour and prediction of entrepreneurial intention among Chinese undergraduates. Social Behavior and Personality, 41(3), 367-376.

39. Yurtkoru, S. Kuşcu, Z.K., \& Doğanay, A. 2014. Exploring the Antecedents of Entrepreneurial Intention on Turkish University Students, Procedia - Social and Behavioral Sciences, 150: 841-850.

40. Yusri, Yusniyati, and K. H. Yee."Malaysian taxpayers' perception towards the implementation of goods and service tax (GST)." International Journal of Economics, Commerce and Research (2015): 1-8.

41. Zapkau, F.B., Schwenk, C., Steinmetz, H., \& Kabst, R. 2015. Disentangling the effect of prior entrepreneurial exposure on entrepreneurial intention, Journal of Business Research ,68,(3): 639-653.

42. Zhang, P., Wang, D. D., \& Owen, C. L. (2015). A study of the entrepreneurial intention of university students. Entrepreneurship Research Journal, 5(1), 61-82. 


\section{AUTHORS PROFILE}

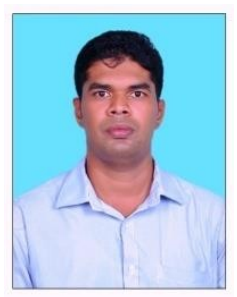

MadhukaraNayak received the B.E. degree in Industrial Production Engineering, M.Tech in Engineering Management, M.B.A in Human Resource Management from Manipal University and currently pursuing Ph.D at Visvesvaraya Technological University. Currently working as a faculty in the Department of Mechanical Engineering, Shri MadhwaVadiraja Institute of Technology \& Management Bantakal, Udupi. He is a Life member of Indian Society for Technical Education (ISTE).

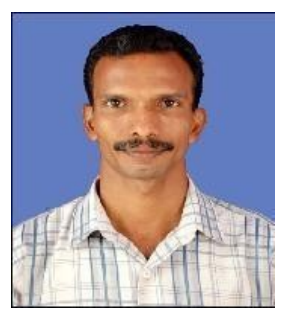

Dr. Narasimha Marakala was born in Avarse Village, Udupi District, Karnataka, India in 1968. He received the B.E.degree in Mechanical Engineering in 1990 And M.Tech. in Advanced Manufacturing Engineering in 1995 from the KREC, Surathkal, and the Ph.D degree in Mechanical engineering from NITK, Surathkal in 2012. He joined as lecturer in 1990 at NMAM Institute of Technology Nitte, Karnataka, India. Now he has been working as a Professor in Mechanical Engineering Department, NMAM Institute of Technology Nitte, Karnataka. He has published more than 15 technical paper in National and international journal and conference. His research interests include fluid and thermal induced vibration in pipes, composite material, and management related to entrepreneurship. He is member of ISTE, IWS. He was the recipient of best paper award for technical paper on "Experimental and Theoretical Investigation of Combined Effect of Fluid and Thermal Induced Vibration in Thin Slender Tube" presented International Conference on Emerging Trends in Engineering held at Dr. J. J. Magdum College of Engineering, Jaysingpur, Maharashtra in2013.

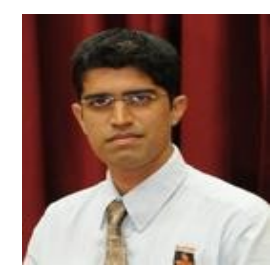

Dr. Vasanth Kamath received B.E. degree in Mechanical Engineering, M.Tech in Manufacturing Engineering, M.B.A in Human Resource and Ph.D. in Knowledge Management and Innovation from Manipal University. Currently working as an Associate Professor in the Department of Operations and Information Science Management, T. A. Pai Management Institute Manipal. 


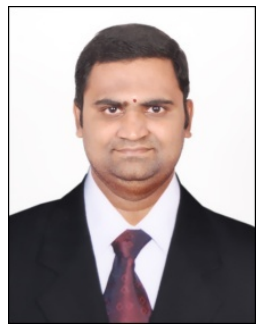

Er. U Saikrishna was born in Vijaywada, Andhra Pradesh, India in the year 1986.He received his B.E.degree from SCSVMV (DU) in year 2008.He then served Darpana Polymers (P) LTD as Maintainace incharge from May 2008 to june 2009.From June 2009 to August 2011.He served Advanced Systems Laboratory, Ministry of Defence as Quality Engineer on Contract Basis. He registered his M.Tech in Manipal Institute Techonology (A Constitutent of Manipal Academy of Higher Education) in year 2011 and after Successful Completion of the Course Work in year 2013; he joined Indian served Indian society for Non-Destructive testing as NDT Trainer and researcher from june 2013 to Januavary 2015.From Januvary 2015 to April 2019 he served as assistant professor in Dhruva Institute of Engineering and Technology, Malla Reddy College of Engineering and Technology (AUTONOMOUS), Koneru Lakshmaih Educational Foundation of Lakshmaih Foundation(DU), Sasi Institute of Technology and Engineering, Indira Institute of Technology and Sciences. He is recognised Chartered Engineer (INDIA) and Certified Engineer(India) and Serving Advanced Systems Laboratory (Ministry of Defence) as Research Engineer on Contract basis presently. He is the Fellow Member of Indian Institution of Engineers, Senior Member of Indian Institution of Engineers, Member of The Institution of Engineers (INDIA),Member of Ultrasonics Society of India, Life Member(Indian Society for Non-Destructructive Testing, Indian Society for Advancement of Materials And Processing Engineering).He Guided 3 U.G students for project and mentored 3 U.G students, Mentored 3 P.G students for Projects. 